\title{
63. PALEOMAGNETIC DIRECTIONS FROM LOWER CRETACEOUS INTERPILLOW LIMESTONES, DEEP SEA DRILLING PROJECT LEG 51, HOLE 417D, BERMUDA RISE
}

\author{
K. Kelts, Deep Sea Drilling Project, La Jolla, California \\ and \\ G. Giovanoli, Geol. Inst., ETH Zürich CH8092, Switzerland
}

\begin{abstract}
Paleomagnetic results from Hole 417D interpillow limestones provide evidence of early infilling and recrystallization. Block tilting or rotation occurred shortly after emplacement and after limestone formation.
\end{abstract}

\section{INTRODUCTION}

This short chapter reports paleomagnetic measurements on three samples of hard limestones (Table 1) encountered below 343 meters of sediment in the upper part of a pillow basalt pile cored in Hole 417D. At several horizons, pillow interstices are completely filled with light greenish to dark greenish limestone, recrystallized from lower Aptian pelagic oozes presumably caught up in lava flows in a rift valley-type setting (see McKenzie and Kelts, this volume).

The paleomagnetic signature of these limestones was considered a key to solve a controversy about possible block rotation at Hole 417D and its timing. Inclinations in the upper basaltic section at Hole 417D differed by about $40^{\circ}$ from both the lowest section and Hole 417A (Bleil and Smith, this volume). The mean stable inclination of $-22^{\circ}$ for Hole $417 \mathrm{~A}$ implies a reasonable latitude of $11.6^{\circ} \pm 3.3^{\circ} \mathrm{N}$ (Bleil and Smith, this volume) for this area during Early Cretaceous. In contrast, the upper 150 meters at Hole 417D, only 400 meters from Hole $417 \mathrm{~A}$, showed a consistent stable inclination of $-66^{\circ}$. This difference was explained by a tectonic rotation of the Hole 417D block (Bleil and Smith, this volume) after extrusion and cooling of the basalts.

In view of the lower intensities of interpillow limestones compared with basalts, we did not determine whether the

TABLE 1

Sample Listing for Paleomagnetic Measurements, Hole 417D

\begin{tabular}{cl}
\hline \multicolumn{1}{c}{ Sample } & \multicolumn{1}{c}{ Description } \\
\hline $22-3,24-27 \mathrm{~cm}$ & $\begin{array}{l}\text { Fine-grained, recrystallized, light greenish gray } \\
\text { limestone with layering marked by scattered } \\
\text { bits of fresh (isotopic) volcanic glass; contains } \\
\text { some relict foraminifers and radiolarians in } \\
\text { relict pellets }\end{array}$ \\
22-7, 18-21 cm & $\begin{array}{l}\text { Hard, moderately coarse grained limestone, of } \\
\text { uniform green color; mostly recrystallized; } \\
\text { contains scattered volcanogenics and quartz } \\
\text { patches } \\
\text { Hard, uniform green, fine-grained, mosaic, }\end{array}$ \\
& $\begin{array}{l}\text { recrystallized limestone; contains some scatter- } \\
\text { ed volcanogenics and minor quartz; there is } \\
\text { some evidence of vague current layering }\end{array}$
\end{tabular}

interpillow limestones showed the same NRM directions as the surrounding limestones.

\section{MEASUREMENTS}

The samples were subjected to a stepwise AF demagnetization for NRM, 50 Oe and 100 Oe magnetizations were first measured on a Digico fluxgate spinner, then checked on a cryogenic apparatus. After AF cleaning from 100 Oe to $400 \mathrm{Oe}$, additional measurements were made solely on the cryogenic magnetometer. Mean inclinations and intensities for seven runs are summarized in Table 2.

\section{DISCUSSION}

The negative inclinations in the limestones are similar, but consistently lower than the basalt values (Table 3 ). Assuming that the measurements record stable magnetization, the following interpretation appears reasonable:

Pillow lavas cooled, acquiring reversed Cretaceous field characteristics from the $M 0$ magnetic period, probably about $-25^{\circ}$ inclination. Interpillow spaces were partly filled with soft carbonate ooze before rotation. Recrystallization of the oozes to limestone must have occurred early - before or during the tectonic rotation of this block - and may have resulted in slightly shallower inclinations or deformation as oozes were caught up in lava flows. A pelagic infilling of void spaces after movement would have led to independent values. If directions diverged greatly, the infill

TABLE 2

Mean Inclinations and Intensities for Seven Runs

\begin{tabular}{|c|c|c|c|c|c|c|c|c|}
\hline $\begin{array}{c}\mathrm{AF} \\
\text { Demagnetization }\end{array}$ & \multicolumn{2}{|c|}{ Declination $\left({ }^{\circ}\right)$} & \multicolumn{3}{|c|}{ Inclination $\left({ }^{\circ}\right)$} & \multicolumn{3}{|c|}{ Intensity $\left(10^{-6} \mathrm{cmu}\right)$} \\
\hline Specimen Section & $22-3$ & $22-7 \quad 28-5$ & $22-3$ & $22-7$ & $28-5$ & $22-3$ & $22-7$ & $28-5$ \\
\hline NRM & & & -43.0 & -53.2 & -51.0 & 7.6 & 10.5 & 16.9 \\
\hline $50 \mathrm{Oe}$ & & & -43.2 & -51.2 & -54.8 & 8.3 & 9.0 & 15.8 \\
\hline \multirow[t]{2}{*}{$100 \mathrm{Oe}$} & $0.0^{\mathrm{a}}$ & $\begin{array}{ll}0.0^{\mathrm{a}} & 0.0^{\mathrm{a}}\end{array}$ & -43.6 & -49.7 & -55.6 & 7.2 & 7.8 & 11.7 \\
\hline & $\begin{array}{l}\text { (mea } \\
\text { SCT. } \\
\text { or tec } \\
\text { mont }\end{array}$ & $\begin{array}{l}\text { ared with } \\
\text { iperconduct- } \\
\text { inology) six } \\
\text { s later }\end{array}$ & & & & & & \\
\hline $100 \mathrm{Oe}$ & & & -42.6 & -46.5 & -64.0 & 7.2 & 8.7 & 11.2 \\
\hline $150 \mathrm{Oe}$ & & & -43.6 & -46.7 & -49.5 & 5.8 & 5.9 & 7.6 \\
\hline $200 \mathrm{Oe}$ & & & -44.8 & -48.2 & -46.4 & 4,86 & 4.7 & 5.7 \\
\hline $250 \mathrm{Oe}$ & & & -44.5 & -48.8 & -39.0 & 4.16 & 3.9 & 4.2 \\
\hline $300 \mathrm{Oe}$ & & & -48.1 & -49.0 & -36.6 & 3.63 & 3.6 & 4.2 \\
\hline $400 \mathrm{Oe}$ & & & -47.3 & -51.6 & -31.3 & 2.62 & 2.53 & 3.05 \\
\hline
\end{tabular}

Arbitrary declinations. 
TABLE 3

Comparison of Limestone Inclinations With Basalt Inclinations, Hole $417 \mathrm{D}^{\mathrm{a}}$

\begin{tabular}{lcc}
\hline $\begin{array}{c}\text { Sample } \\
\text { (Interval in cm) }\end{array}$ & $\begin{array}{c}\text { Limestone } \\
\text { (at 100 Oe) }\end{array}$ & Basalt \\
\hline $22-3,24-27$ & $-43.6^{\circ}$ & \\
$22-4,18-21$ & & $-63.1^{\circ}$ \\
$22-5,57-60$ & & $-67.6^{\circ}$ \\
$22-6,18-21$ & $-49.7^{\circ}$ & $-51.6^{\circ}$ \\
$22-7,18-21$ & $-55.5^{\circ}$ & $-63.1^{\circ}$ \\
$28-4,102-104$ & & $-68.2^{\circ}$ \\
$28-5,9-12$ & & $-27.8^{\circ}$ \\
$28-6,30-33$ & $+42.9^{\circ}$ \\
Paleoclination for mid-Cretaceous paleosite & Present inclination at Hole 417D & \\
\hline
\end{tabular}

${ }^{\mathrm{a}}$ From Bleil and Smith, this volume.

would have been after tectonic movement. Since the limestone and pillow basalts have similar directions, we suggest they were tilted together after the limestones had acquired a stable depositional remanence. Thermal magnetization from basalts is unlikely as temperatures in these void spaces were hardly high enough.
The precise timing of the tectonic tilting of the pillow block at Hole 417D is therefore difficult to achieve. The sedimentary cover seems to follow rotation. Although disturbed, the soft, thinly laminated lower Aptian chalks that directly overlie these basalts seem to be horizontally layered, which would suggest an onlapping after tilt. Cherts with large volcaniclastic breccia components occur 1 meter above basalt, as beds of possible late Aptian age; this may be an indirect clue to the time of tectonic movement. There appears to be a small hiatus between lower Aptian and lower Albian at this site. Unfortunately, it was not possible to perform NRM determinations on the basal chalks.

In summary, paleomagnetic evidence supports a model with early tilting and recrystallization of pelagic carbonate oozes. This confirms earlier evidence from observations of quartz and calcite mosaics enclosing isotopic glass (McKenzie and Kelts, this volume). The inclinations also support suggestions of tectonic tilting after limestones formed but before a significant sediments cover had developed.

\section{ACKNOWLEDGMENTS}

We thank Bill Lowrie for the use of the instruments of the Inst. f. Geophysik, ETH-Zürich, and Ulrich Bleil and Brigitte Smith for their suggestion of this study, which was supported by the Swiss National fund. 